\title{
STRATEGI PENINGKATAN DAYA SAING INDUSTRI FURNITURE ROTAN INDONESIA DI KAWASAN ASEAN DAN TIONGKOK
}

\author{
Rudi Eko Setyawan*1, Henny K Daryanto*), dan Rina Oktaviani**) \\ *) Sekolah Bisnis - Institut Pertanian Bogor \\ Jl. Raya Pajajaran, Bogor 16151 \\ **) Departemen Ilmu Ekonomi, Fakultas Ekonomi dan Manajemen, Institut Pertanian Bogor \\ Gedung FEM Lantai 2, Jl. Kamper, Kampus IPB Dramaga, Bogor 16680
}

\begin{abstract}
Competitiveness of a country's export commodities is one of the indicators used to measure its economic progress. This study aims to analyze the competitiveness of Indonesian rattan furniture in China and the ASEAN region, along with the influencing factors and to conclude appropriate strategies to improve its competitiveness. The analysis was conducted by utilizing Diamond's Porter, Normalized Revealed Comparative Advantage (NRCA), and panel data regression. The results showed that the competitiveness of Indonesian rattan furniture in the ASEAN region and China, in the period of 2001 to 2014, is fluctuated with small level of competitiveness. This notion can be seen from all of the positive NRCA index values. In the Fixed Effects Model (FEM), the independent variables that significantly influence NRCA include the export prices and volumes, global prices of rattan furniture and raw rattan, the number of rattan industries, production of real rattan, production value of rattan, investment of rattan industry, direct labor of rattan industry, interest rate of Bank loans, implementation of ACFTA and violation policy of raw and semi-finished rattan exports. To increase the competitiveness of Indonesian rattan furniture, the government is urged to establish a development or training center for the innovative designs and improvement of quality standard of Indonesian rattan furniture. This is also supported by a guarantee of rattan raw material availability and technological improvement of rattan processing industry. Thus, the third step to perform is the improvement of infrastructure and distribution chain, improvement of market information systems, and strengthening of brand image of rattan furniture in Indonesia.
\end{abstract}

Keywords: competitiveness of rattan furniture, diamond's porter, normalized revealed comparative advantage, fixed effect model

\begin{abstract}
ABSTRAK
Daya saing komoditas ekspor negara merupakan salah satu indikator yang digunakan untuk mengukur kemajuan ekonomi suatu negara. Penelitian ini bertujuan untuk menganalisis daya saing furniture rotan Indonesia di kawasan ASEAN Tiongkok serta faktor-faktor yang memengaruhinya dan kemudian menyimpulkan strategi yang tepat untuk meningkatkan daya saingnya. Analisis dilakukan dengan menggunakan Diamond's Porter, Normalized Revealed Comparative Advantage (NRCA) dan regresi data panel. Hasil penelitian menunjukkan bahwa daya saing furniture rotan Indonesia di kawasan ASEAN dan Tiongkok dalam kurun waktu 2001 hingga 2014 berfluktuasi dan sebenarnya masih mempunyai daya saing meskipun kecil, hal ini dapat dilihat dari semua nilai indeks NRCA nilainya positif. Pada Fixed Effect Model (FEM), variabel independen yang berpengaruh signifikan terhadap NRCA adalah harga ekspor, volume ekspor, harga furniture rotan dunia, harga rotan mentah dunia, jumlah perusahaan industri rotan di Indonesia, produksi rotan riil di Indonesia, nilai produksi rotan di Indonesia, investasi industri rotan di Indonesia, tenaga kerja langsung industri rotan, besarnya suku bunga pinjaman Bank, pemberlakuan ACFTA dan kebijakan pelarangan ekspor rotan mentah maupun setengah jadi. Untuk mampu meningkatkan daya saing furniture rotan Indonesia, pemerintah harus mendirikan pusat pengembangan atau pelatihan dan pengembangan desain yang inovatif maupun standart mutu furniture rotan Indonesia. Hal ini juga didukung dengan adanya jaminan ketersediaan bahan baku rotan dan peningkatan teknologi industri pengolahan rotan. Hal ketiga yang perlu dilakukan adalah perbaikan infrastruktur maupun rantai distribusi, perbaikan sistem informasi pasar rotan serta penguatan brand image furniture rotan Indonesia.
\end{abstract}

Kata Kunci: daya saing furniture rotan, diamond's porter, normalized revealed comparative advantage, fixed effect model

\footnotetext{
${ }^{1}$ Alamat Korespondensi:

Email: rudy.voo@gmail.com
} 


\section{PENDAHULUAN}

Persaingan penjualan produk hasil kerajinan tangan dan furniture berbahan baku rotan saat ini tidak hanya terjadi di tingkat nasional seperti di tingkat antar pedagang, melainkan juga telah merambah pasar internasional. Hal ini karena sejak satu dekade terakhir beberapa negara mulai menyadari tingginya nilai ekonomis yang bisa diperoleh melalui berbagai improvisasi dan pengembangan produk pada berbagai hasil kerajinan dan furniture berbahan dasar rotan. Dampaknya, kini perdagangan rotan dunia tidak hanya didominasi oleh pengusaha Indonesia, tetapi juga pengusaha yang berasal dari negara-negara maju seperti Tiongkok, Taiwan dan Eropa.

Menurut data UN Comtrade Database 2015 sepanjang Tahun 2013, Indonesia tidak termasuk dalam lima besar pengekspor industri furniture rotan ke seluruh dunia, padahal Indonesia merupakan produsen bahan baku rotan dunia. Hal tersebut dikarenakan Indonesia sebagai produsen utama bahan baku rotan dunia belum mampu menguasi pasar ekspor furniture dan produk olahan rotan lainnya di kawasan Internasional seperti ditampilkan pada Gambar 1.

Rotan merupakan komoditas hasil hutan non-kayu yang sempat menjadi primadona dunia. Namun, ketenaran rotan semakin menurun dengan semakin banyaknya pesaing yang berasal dari rotan sintetis dan berbagai isu lingkungan yang berkembang menyertainya. Kehadiran rotan sintetis yang terbuat dari bahan plastik Polyethilene dan Polyvinyl Chloride (PVC) menjadi pesaing utama dari produk rotan. Berdasarkan penelitian yang dilakukan ITPC Lyon (2011) dan Anwar et al. (2014), bahan sintetis lebih dipilih karena bahan sintetis lebih awet, karena tidak terkena kutu, rayap ataupun pin hole. Alasan lainnya adalah bahan sintetis lebih mudah dibersihkan, lebih ringan juga hasil anyamannya lebih rapi karena rotan sintetis lebih lentur. Disamping faktor tersebut, rotan sintetis memiliki lebih banyak pilihan warna dan harganya lebih murah jika dibandingkan dengan rotan asli. Selain itu, rotan asli juga sulit diperbaiki ketika rusak.

Data UN Comtrade Database (2015) pada Gambar 2, nilai ekspor furniture rotan Indonesia ke kawasan ASEAN dan Tiongkok dari dalam kurun waktu 20012014, kinerja ekspor furniture rotan asal Indonesia menunjukkan tren yang rata-rata selalu naik. Namun, terjadi hal yang sangat kontras dengan fakta yang terjadi pada Tahun 2013. Pemberlakuan kebijakan larangan ekspor rotan mentah dan setengah jadi pada awal Tahun 2012 dapat meningkatkan volume ekspor furniture rotan Indonesia secara signifikan. Setahun setelah kebijakan tersebut diberlakukan justru membuat jumlah volume ekspor furniture rotan terjadi penurunan drastis sebesar $15 \%$.

Penelitian yang terkait dengan analisis daya saing dan strategi pengembangan industri rotan Indonesia telah dilakukan oleh Syahresmita (2000), dimana alternatif strategi yang lebih diprioritaskan adalah menciptakan iklim usaha kondusif, diikuti oleh peningkatan promosi dan informasi pasar serta penguatan keterkaitan aktivitas dalam rantai nilai.

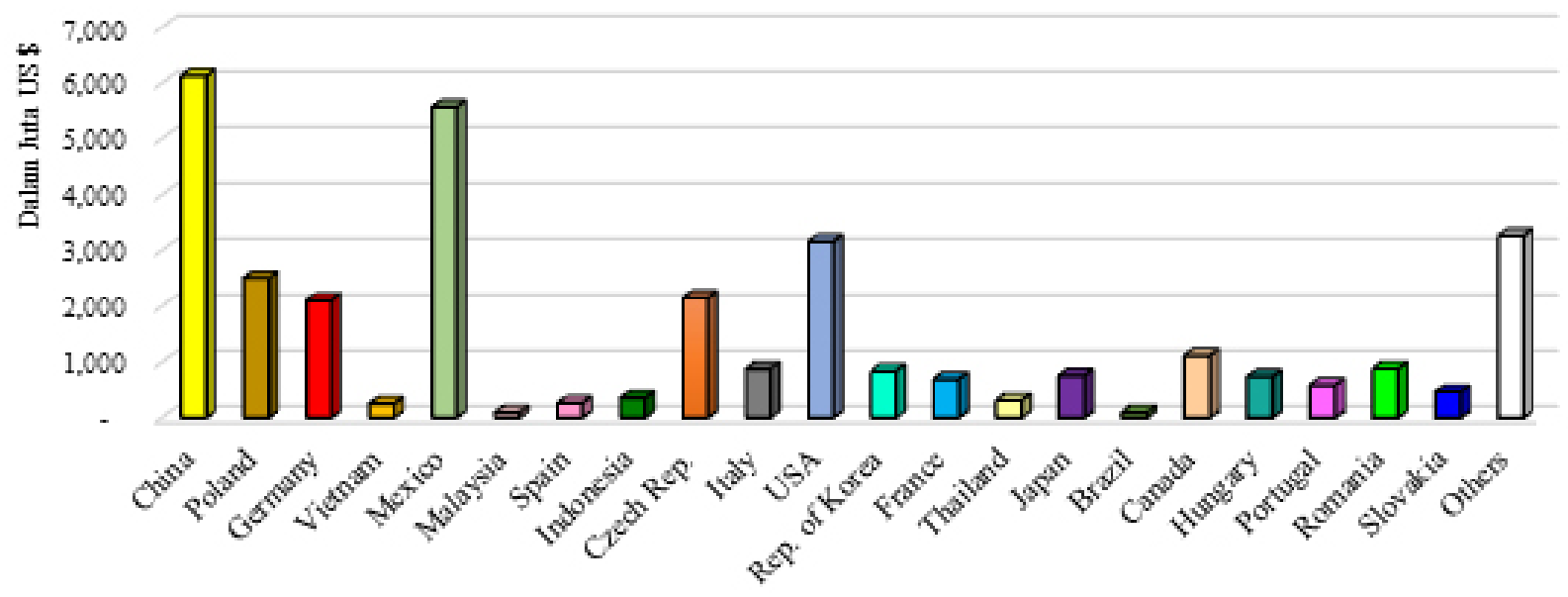

Gambar 1. Negara pengekspor industri furniture rotan dunia tahun 2014 (UN Comtrade Database 2015) 


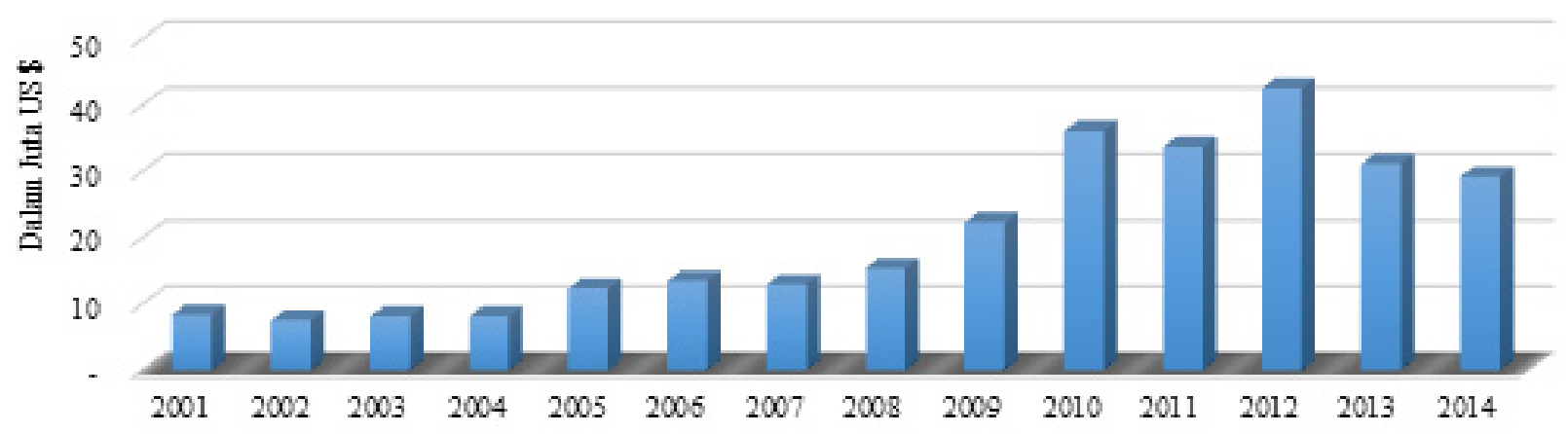

Gambar 2. Nilai ekspor furniture rotan Indonesia ke ASEAN dan Tiongkok (UN Comtrade Database 2015)

Industri furniture rotan di dalam negeri memang harus mengalami perjuangan berat menghadapi persaingan di pasar global. Salah satu kendala besar yang dihadapi adalah tingkat ketersediaan bahan baku rotan di dalam negeri yang kadang membuat frustasi para pengusaha furniture rotan seiring dengan bertumbuhnya produk rotan sintetis dengan harga yang lebih murah. Hal ini mengakibatkan industri furniture rotan dalam negeri lebih memilih bahan baku rotan sintetis daripada bahan baku rotan asli dari Indonesia yang terkenal dengan kualitas rotan unggulan yang dimilikinya.

Penelitian ini bertujuan: 1) menganalisis daya saing produk ekspor furniture rotan Indonesia di kawasan ASEAN dan Tiongkok; 2) menganalisis faktor-faktor yang memengaruhi daya saing produk furniture rotan Indonesia di kawasan ASEAN dan Tiongkok; 3) menentukan strategi kompetitif yang tepat untuk mendukung peningkatan daya saing industri furniture rotan Indonesia di kawasan ASEAN dan Tiongkok.

\section{METODE PENELITIAN}

Data yang digunakan dalam penelitian ini adalah data primer dan sekunder yang berasal dari beberapa responden atau instansi yang terkait dengan objek penelitian. Adapun data sekunder yang digunakan adalah data panel yang menggabungkan time series 2001-2013 dan data cross section enam negara yaitu Tiongkok, Malaysia, Philipina, Singapura, Thailand dan Vietnam.

Keunggulan kompetitif dalam penelitian ini dianalisis dengan menggunakan pendekatan Porter's Diamond. Metode ini merupakan metode kualitatif yaitu menganalisis tiap komponen dalam Porter's Diamond (Porter 1990 dalam Nayantakaningtyas dan Daryanto,
2012), yaitu Factor Condition (FC), Demand Condition (DC), Related and Supporting Industries (RSI), Firm Strategy, Structure, and Rivalry (FSSR). Selain itu terdapat komponen lain yang terkait dengan keempat komponen utama tersebut yaitu peran pemerintah dan kesempatan.

Indeks Revealed Comparative Advantage (RCA) menggambarkan keunggulan komparatif atau daya saing ekspor dari suatu negara dalam suatu komoditas terhadap dunia. Namun demikian, RCA memiliki keterbatasan, menurut Yeats (1985) dalam Hermawan (2012) nilai RCA ini terdapat masalah ketika melakukan perbandingan nilai ordinal dan cardinal. Ada beberapa penelitian lanjutan terkait modifikasi indeks RCA dan salah satu yang cukup terkini adalah indikator Normalized Revealed Comparative Advantage (NRCA) yang diakukan oleh Yu et al. (2009). Nilai indeks NRCA lebih baik dan akurat hasilnya berdasarkan penelitian yang dilakukan oleh Sanidas dan Shin (2010). NRCA memiliki rumusan sebagai berikut:

$$
N R C A=\frac{\Delta X_{i j}}{X_{w}}=\frac{X_{i j}}{X_{w}}-\frac{X_{w j} X_{i}}{X_{w} X_{w}}
$$

Dimana X menyatakan nilai ekspor, indeks $\mathrm{i}, \mathrm{w}$, dan $\mathrm{j}$ masing-masing menunjukkan agregat ekspor pada level negara, regional atau dunia, dan komoditas. Rentang nilai NRCA adalah -0,25-0,25 dengan Comparative Advantage Neutral (CAN) adalah nol. Sebagai gambaran, $-0,25<\mathrm{NRCA}_{\mathrm{ij}}<0$ menunjukkan bahwa ekspor sebenarnya dari negara i untuk komoditas $\mathrm{j}$ lebih rendah daripada comparative advantage-neutral point, sementara $0<\mathrm{NRCA}_{\mathrm{ij}}<0,25$ menunjukkan bahwa negara i memiliki keunggulan komparatif dalam ekspor komoditas j. 
Data panel merupakan gabungan dari data cross section dan data time series sehingga jumlah pengamatan menjadi sangat banyak. Ada tiga teknik untuk mengestimasi model regresi data panel (Nachrowi, 2006) dalam (Silalahi et al. 2014), yaitu:

1. Common Effect Model (CEM) adalah metode regresi yang hanya mengkombinasikan data time series dan cross section dalam bentuk pool, mengestimasinya dengan menggunakan pendekatan kuadrat terkecil (pooled Least square). Persamaan metode ini dapat ditulis sebagi berikut:

$$
Y_{i t}=\alpha+\beta_{j} X_{i t}^{j}+\varepsilon_{i t}
$$

2. Fixed Effect Model (FEM) adalah metode regresi yang mengestimasi data panel dengan menambahkan variabel Dummy. Model ini mengasumsikan bahwa terdapat efek yang berbeda antar individu.

$$
Y_{i t}=\alpha_{i}+\beta_{j} X_{i t}^{j}+\sum_{i=2}^{n} \alpha_{i} D_{i}+\varepsilon_{i t}
$$

3. Random Effect Model (REM) adalah metode regresi yang mengestimasi data panel dengan menghitung error dari model regresi dengan metode Generalized Least Square (GLS). Persamaan random effect dapat ditulis sebagai berikut:

$$
\begin{aligned}
& Y_{i t}=\alpha+\beta_{j} X_{i t}^{j}+\varepsilon_{i t} \\
& \varepsilon_{i t}=u_{i}+V_{t}+W_{i t}
\end{aligned}
$$

Keterangan:

$\mathrm{Y}_{\text {it }} \quad$ : Variabel terikat untuk individu ke-I pada waktu ke-t

: Variabel bebas ke-j untuk individu ke-i pada waktu ke-t

i : Unit cross section sebanyak N

t : Unit time series sebanyak $\mathrm{T}$

$\mathrm{j}$ : Urutan variabel

$\varepsilon_{\text {it }} \quad$ : Komponen error untuk individu ke-i pada waktu ke-t

$\alpha \quad$ : intercept

$\beta \mathrm{j} \quad$ : Parameter untuk variabel ke- $\mathrm{j}$

$\mathrm{u}_{\mathrm{i}} \quad$ : Komponen error cross section

$\mathrm{V}_{\mathrm{t}}$ : Komponen error time series

$\mathrm{W}_{\text {it }}$ : Komponen error gabungan
Melalui serangkaian tahapan beberapa metode analisis kuantitatif dan kualitatif, kerangka pemikiran dalam penelitian ini dapat dilihat pada Gambar 3.

\section{Hipotesis Penelitian}

Berdasarkan permasalahandan alurkerangka pemikiran, maka hipotesis yang digunakan dalam penelitian ini, antara lain yaitu sebagai berikut:

1. Industri furniture rotan Indonesia mempunyai daya saing yang tinggi di kawasan ASEAN dan Tiongkok.

2. Industri furniture rotan Indonesia memiliki peningkatan kinerja ekspor di pasar Internasional.

3. Seluruh variabel bebas memiliki pengaruh terhadap variabel tidak bebas (daya saing furniture rotan Indonesia/ NRCA).

\section{HASIL}

\section{Faktor-faktor Penentu Daya Saing Industri Furniture Rotan Indonesia Berdasarkan Konsep Porter's Diamond}

Dunia usaha furniture rotan di Indonesia pada saat ini menghadapi kondisi yang cukup serius. Hal ini diindikasikan dengan volume dan nilai ekspor furniture rotan yang terus menurun. Menurut Sumardjani (2009) kondisi furniture rotan yang memprihatinkan ini bila ditinjau ke belakang adalah akibat dari kebijakan pemerintah yang tidak strategis. Kebijakan yang telah diambil hanyalah melarang dan memperbolehkan ekspor rotan asalan atau rotan setengah jadi tanpa melakukan pertimbangan dan analisis yang komprehensif. Pemerintah beranggapan bahwa dengan mengatur pasokan bahan baku, seluruh industri rotan bisa dikontrol sesuai dengan yang diharapkan, padahal komponen bahan baku yang diakomadasikan dalam kebijakan-kebijakan tersebut hanyalah salah satu dari lima kondisi lingkungan industri menurut Michael Porter (1998). Porter (1998) dalam Daryanto (2004) menyatakan bahwa keunggulan daya saing dari suatu negara ditentukan dan diciptakan oleh beberapa faktor penentu yaitu faktor kondisi, strategi, sturktur dan persaingan, kondisi permintaan, industri yang berkaitan dan mendukung serta faktor yang memengaruhi faktor penentu yaitu pemerintah dan peluang. 
Konsep yang dikemukakan oleh Michael Porter dalam Diamond's Porter dalam Karagiannopoulos et al. (2005), Kirchner (2012) dan Dobbs (2012) dapat digunakan untuk analisis industri dan perkembangan strategi perusahaan untuk melihat kemenarikan pasar. Kemenarikan pasar dalam konteks ini merujuk pada profitability keseluruhan industri. Industri menjadi tidak "menarik" bila kombinasi kekuatan bergerak menurunkan keseluruhan profitability, sedangkan bila kondisi pasar industri bergerak menuju "kompetisi murni" maka industri dianggap benar-benar tidak menarik.

a. Kondisi faktor produksi rotan di Indonesia

Kondisi faktor yang berpengaruh terhadap daya saing furniture rotan Indonesia:

\section{Sumberdaya alam}

Salah satu produk hasil hutan bukan kayu yang memiliki nilai pasar tinggi adalah rotan. Indonesia sebenarnya mampu memasok kebutuhan rotan dunia. Namun hal ini tidak didukung oleh produktivitas dan kualitas dari furniture rotan Indonesia dikarenakan bahan baku furniture rotan sebagian besar masih mengandalkan rotan alam yang dipungut langsung dari dalam hutan dan diolah dengan teknologi yang masih sederhana.

\section{Sumberdaya manusia}

Secara umum, tenaga kerja yang dipakai dalam industri furniture rotan di Indonesia masih kurang terdidik. Rendahnya tingkat pendidikan pelaku bisnis furniture rotan mengakibatkan rendahnya motivasi dan inovasi furniture rotan di Indonesia.

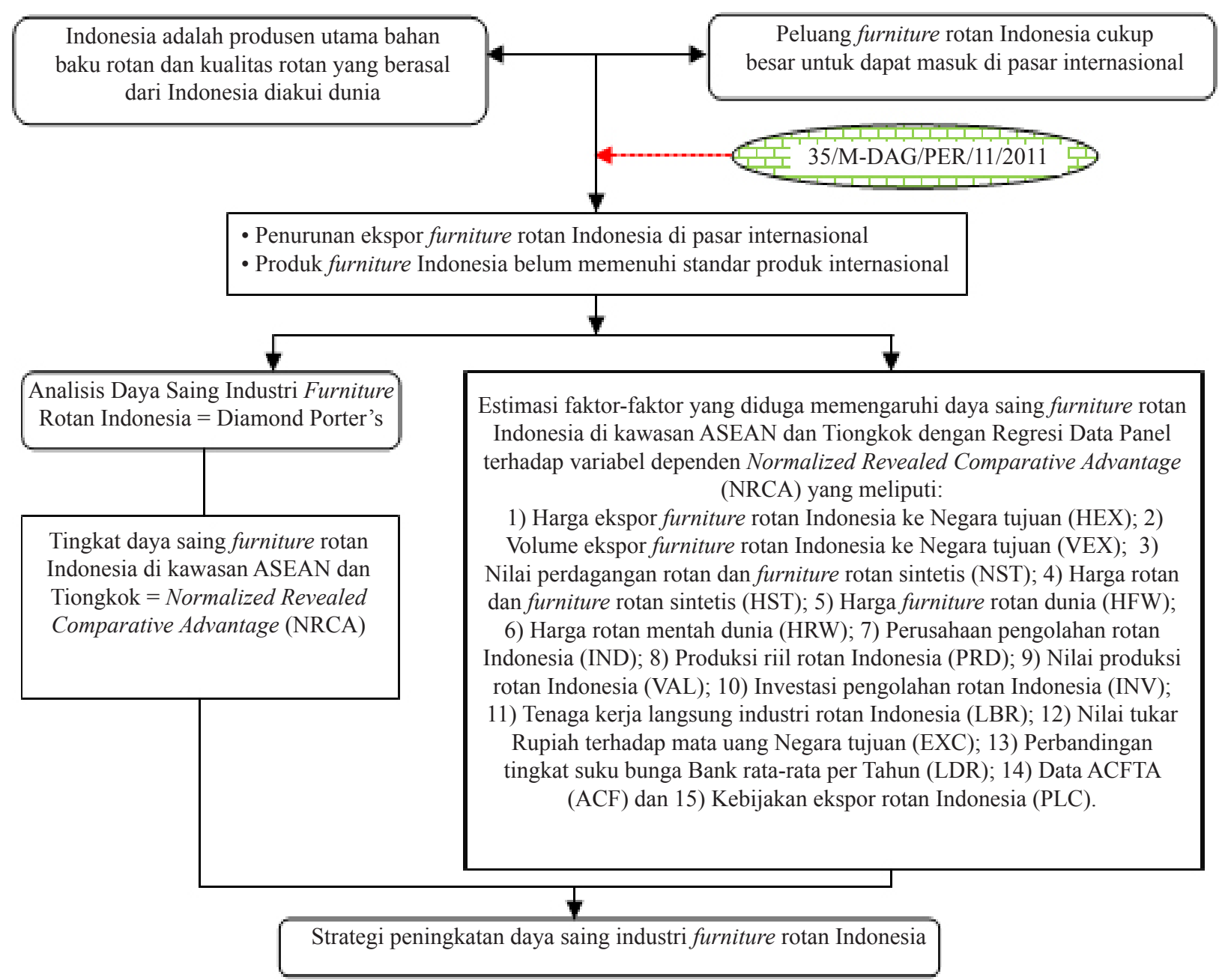

Gambar 3. Kerangka pemikiran penelitian 


\section{Sumberdaya ilmu pengetahuan dan teknologi}

Penguasaan teknologi dari mulai pemanenan, distribusi hingga produksi pada akhirnya berdampak pada peningkatan daya saing industri furniture rotan Indonesia. Di sisi lain, teknologi pengolahan rotan di Indonesia masih menggunakan teknologi yang tradisional. Begitu juga penerapan teknologi informasi yang diharapkan mampu menyebarluaskan informasi yang dibutuhkan bagi para pelaku dan konsumen produk.

\section{Sumberdaya modal}

Sejumlah upaya dilakukan pemerintah untuk meminimalisasi dampak dari pelarangan ekspor bahan baku rotan dalam jangka pendek. Di antaranya dorongan ke arah optimalisasi produksi industri pengolahan rotan di dalam negeri, sehingga bisa menyerap rotan dari pengumpul/pengepul sebanyak mungkin. Hal ini dilakukan untuk mengembangkan industri furniture rotan di Indonesia.

\section{Sumberdaya infrastruktur}

Sarana dan prasarana fisik ini meliputi sarana dan prasarana pemanenan rotan, sarana dan prasarana penyimpanan dan pengangkutan, transportasi dan telekomunikasi. Sarana dan prasarana tersebut merupakan syarat mutlak bagi sektor hulu dan hilir dari industri furniture rotan dalam hal pendistribusian bahan baku maupun produk olahan rotan.

\section{b. Kondisi permintaan furniture rotan Indonesia}

Kondisi industri furniture rotan Indonesia saat ini kalah bersaing dengan barang sejenis asal Tiongkok dan Eropa, baik itu dipasar domestik maupun ekspor. Padahal Indonesia mempunyai bahan baku rotan yang melimpah. Masalah utamanya ternyata adalah lemahnya penguasaan desain, finishing, hingga branding pada furniture rotan tersebut. Desain furniture rotan Indonesia memang belum berkembang. Saat ini, desain dari furniture rotan Indonesia yang dijual masih mengikuti permintaan pasar. Selain itu, belum adanya ketersediaan desain asli produk furniture rotan Indonesia atas permintaan dari luar negeri. c. Industri terkait dan pendukung industri furniture rotan indonesia

Pada industri terkait ekspor furniture rotan meliputi industri penyediaan bahan baku rotan mentah maupun setengah jadi. Pada industri pendukung memiliki peran dalam pengembangan produk furniture rotan. Industri furniture rotan tentunya sangat tergantung pada kemampuan industri hulu menyediakan bahan baku yang unggul. Namun, permasalahan yang ada sekarang adalah susahnya mencari pemasok bahan baku maupun rotan setengah jadi untuk pembuatan furniture rotan itu sendiri. Mahalnya harga bahan penunjang untuk memproduksi furniture rotan juga menjadi kendala dalam pengembangan industri furniture rotan di Indonesia.

d. Strategi, struktur, dan rivalitas industri furniture rotan di Indonesia

Pengembangan industri furniture rotan di Indonesia seharusnya menjadi perhatian khusus dari pemerintah apabila ingin berhasil dalam mengembangkan daya saing furniture rotan Indonesia di pasar Internasional. Turunnya daya saing furniture rotan Indonesia dari segi strategi disebabkan oleh kualitas furniture rotan Indonesia masih rendah apabila dibandingkan dengan furniture rotan dari negara lain, marketing campaign furniture rotan Indonesia belum bagus, brand image furniture rotan Indonesia kurang bagus, informasi permintaan pasar dan regulasi negara tujuan ekspor belum tersedia bagi eksportir furniture rotan Indonesia, serta promosi ekspor dan layanan purna jual untuk furniture rotan Indonesia masih buruk.

Strategi pengembangan industri furniture rotan Indonesia harus direncanakan dengan baik sejak sekarang. Strategi tersebut perlu dirancang menjadi suatu struktur usaha yang dikelola dan berorientasi pada pengembangan industri dari hulu sampai ke hilir sehingga siap menghadapi berbagai perubahan yang terjadi. Program penguatan struktur industri dilakukan melalui sinergi dan koordinasi dari berbagai pihak, baik antar kementerian terkait dari pihak pemerintah maupun para pelaku usaha seperti pemungut rotan, pedagang, pengolah, eksportir dan asosiasi, termasuk lembaga perbankan dan LSM. Keterlibatan para pemangku kepentingan ini akan menjadi kunci sukses pengembangan industri furniture rotan di Indonesia, karena mengingat struktrur industri rotan di Indonesia terjadi anomali, dimana harga rotan di petani yang 
masih sangat rendah dan mahalnya bahan baku rotan setengah jadi untuk produksi furniture rotan. Oleh karena itu, mengakibatkan supply rotan menjadi tidak stabil.

Adanya persaingan industri furniture rotan di kawasan ASEAN dan Tiongkok juga dapat meningkatkan daya saing furniture rotan Indonesia. Persaingan yang ketat akan mendorong industri furniture rotan dari Indonesia semakin meningkatkan kemampuannya dalam aspek sumber daya modal, inovasi dan teknologi, efisiensi dan produktifitas, kualitas dan layanan, diversifikasi produk furniture rotan dan akses pasar ke luar negeri. Ancaman pesaing yang merupakan pendatang baru dalam bahasa Porter adalah industri furniture rotan yang berasal dari Hongkong, Vietnam, Taiwan, dan Tiongkok. Industri furniture rotan yang berasal dari empat negara itu dikatakan sebagai pendatang baru karena industriindustri tersebut tumbuh setelah industri bahan baku rotan Indonesia tumbuh. Dalam sudut pandang yang lain dapat dikatakan bahwa sesungguhnya Indonesialah yang menjadi pendatang baru dalam industri furniture rotan dunia (Sumardjani, 2009). Hal penting yang harus diperhatikan adalah harga produk yang cenderung semakin bersaing sehingga mengakibatkan permintaan furniture rotan yang beralih ke produk furniture rotan artificial atau synthetic rattan yang bahan bakunya adalah polyethylene serta adanya diversifikasi produk furniture dari negara penghasil rotan.

\section{e. Peran pemerintah}

Pemerintah dapat memfasilitasi lingkungan industri yang mampu memperbaiki kondisi penentu daya saing sehingga perusahaan-perusahaan yang berada dalam industri mampu mendayagunakan faktor-faktor penentu tersebut secara efektif dan efisien. Pemerintah dapat memengaruhi aksesibilitas pelaku-pelaku industri furniture rotan terhadap berbagai sumberdaya melalui kebijakan-kebijakannya, seperti sumberdaya alam, tenaga kerja, pembentukan modal serta sumberdaya ilmu pengetahuan, teknologi dan informasi (IPTEK).

\section{f. Peran kesempatan}

Perdagangan bebas ASEAN-China Free Trade Area (ACFTA) yang dimulai pada awal tahun 2010 mengadopsi sistem baru, yaitu sistem yang bebas hambatan. Tarif dan bea masuk yang selama ini dianggap sebagai penghambat telah dihapuskan agar semua komoditas yang diperdagangkan mendapat perlakuan sama di kawasan tersebut. Selain ACFTA, perbandingan tingkat suku bunga pinjaman Bank di Indonesia dengan negara ASEAN dan Tiongkok juga memengaruhi daya saing furniture rotan Indonesia di kawasan ASEAN dan Tiongkok.

\section{Tingkat Daya Saing Furniture Rotan Indonesia di Kawasan ASEAN dan Tiongkok}

Pada Gambar 4 walaupun nilai NRCA tidak ada yang negatif. Namun, angkanya cukup kecil, bahkan kurang dari 0,0025. Pada Gambar 4 dapat dilihat bahwa selama periode 2001 sampai 2014, nilai NRCA furniture rotan Indonesia nilainya tidak ada yang negatif. Nilai tertinggi adalah NRCA ke pasar Malaysia diikuti ke pasar Vietnam. Artinya, daya saing furniture rotan Indonesia di pasar Malaysia dan Vietnam adalah kuat. Nilai NRCA furniture rotan Indonesia ke pasar Tiongkok, Philipina, Thailand dan Singapore nilainya kecil. NRCA yang terkecil adalah ke pasar Filipina. Hal ini dapat dikatakan daya saing furniture rotan Indonesia di pasar Filipina adalah paling lemah, mengingat Filipina juga termasuk negara penghasil rotan di dunia.

\section{Estimasi Faktor-faktor yang Diduga Memengaruhi Daya Saing Furniture Rotan Indonesia di Kawasan ASEAN dan Tiongkok}

Hasil estimasi model regresi FEM terhadap variabel dependen NRCA menunjukkan bahwa nilai probabilitas variabel harga ekspor furniture rotan Indonesia ke ASEAN dan Tiongkok (HEX), volume ekspor furniture rotan Indonesia ke ASEAN dan Tiongkok (VEX), harga furniture rotan dunia (HFW), harga rotan mentah dunia (HRW), jumlah perusahaan pengolahan rotan Indonesia (IND), produksi riil rotan Indonesia (PRD), nilai produksi rotan Indonesia (VAL), investasi pengolahan rotan Indonesia (INV), tenaga kerja langsung industri rotan Indonesia (LBR) perbandingan lending rate dengan Negara tujuan ekspor (LDR), pemberlakuan ACFTA yang dimulai pada tahun 2010 (ACF) dan kebijakan ekspor rotan di Indonesia (PLC) mempunyai nilai yang lebih kecil dari taraf nyata $5 \%$. Hal ini menunjukan bahwa 12 variabel tersebut berpengaruh signifikan terhadap daya saing furniture rotan Indonesia di kawasan ASEAN dan Tiongkok. Model yang diperoleh dari Regresi FEM dengan pembobotan cross-section SUR selengkapnya dapat dilihat pada Tabel 2 . 


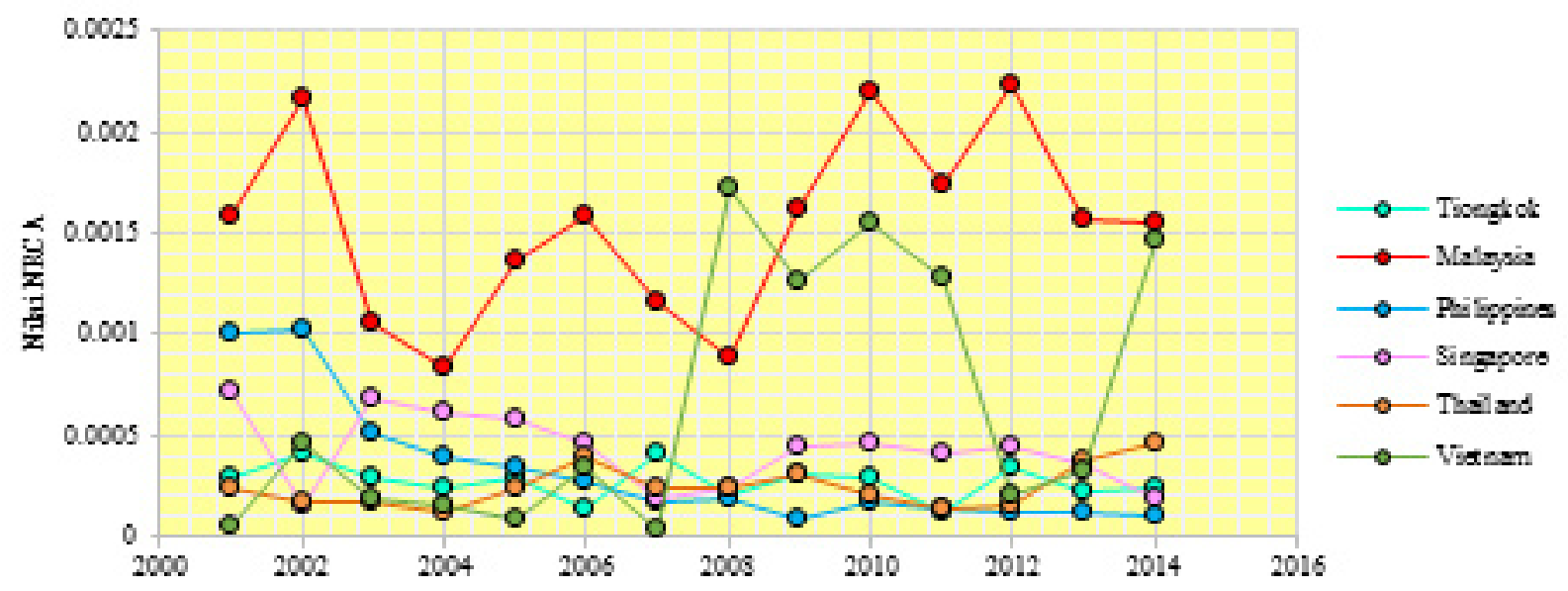

Gambar 4. Nilai NRCA Furniture Rotan Indonesia di Kawasan ASEAN dan Tiongkok UN Comtrade Database 2015 (diolah)

Tabel 2. Model regresi FEM terhadap variabel dependen NRCA

\begin{tabular}{lcccc}
\hline \multicolumn{1}{c}{ Variabel } & Koefisien & Standar Error & t-Statistic & Probabilitas \\
\hline Konstanta (C) & $-1,15 \times 10-2$ & $4,93 \times 10-4$ & $-23,3817$ & 0,0000 \\
Harga export furniture rotan (HEX) & $1,20 \times 10-4$ & $1,05 \times 10-5$ & 11,3932 & $0,0000^{*}$ \\
Volume export furniture rotan (VEX) & $1,53 \times 10-10$ & $1,91 \times 10-11$ & 8,0087 & $0,0000^{*}$ \\
Nilai perdagangan rotan sintetis (NST) & $1,18 \times 10-12$ & $2,76 \times 10-12$ & 0,4262 & 0,6720 \\
Harga rotan sintetis (HST) & $4,20 \times 10-6$ & $1,94 \times 10-5$ & 0,2162 & 0,8298 \\
Harga furniture rotan dunia (HFW) & $-1,95 \times 10-4$ & $1,45 \times 10-5$ & $-13,4339$ & $0,0000^{*}$ \\
Harga rotan mentah dunia (HRW) & $1,56 \times 10-4$ & $7,51 \times 10-6$ & 20,7545 & $0,0000^{*}$ \\
Perusahaan industri rotan Indonesia (IND) & $2,25 \times 10-5$ & $1,13 \times 10-6$ & 19,9827 & $0,0000^{*}$ \\
Produksi riil rotan di Indonesia (PRD) & $-1,26 \times 10-8$ & $5,46 \times 10-10$ & $-23,0213$ & $0,0000^{*}$ \\
Nilai produksi furniture rotan (VAL) & $5,91 \times 10-12$ & $2,93 \times 10-13$ & 20,1974 & $0,0000^{*}$ \\
Investasi pengolahan rotan Indonesia (INV) & $2,10 \times 10-11$ & $1,58 \times 10-12$ & 13,3056 & $0,0000^{*}$ \\
Tenaga kerja langsung industri rotan (LBR) & $-5,46 \times 10-9$ & $2,83 \times 10-10$ & $-19,2850$ & $0,0000^{*}$ \\
Exchange rate ke mata uang Negara j(EXC) & $-1,93 \times 10-8$ & $3,14 \times 10-8$ & $-0,6154$ & 0,5414 \\
Perbandingan lending rate Negara j(LDR) & $-1,82 \times 10-4$ & $5,43 \times 10-5$ & $-3,3573$ & $0,0016^{*}$ \\
ASEAN-China Free Trade Agreement (ACF) & $-5,11 \times 10-4$ & $4,05 \times 10-5$ & $-12,6208$ & $0,0000^{*}$ \\
Kebijakan ekspor rotan di Indonesia (PLC) & $1,30 \times 10-3$ & $6,46 \times 10-5$ & 20,1153 & $0,0000^{*}$ \\
\hline \multicolumn{1}{c}{ Statistik dengan pembobot } \\
\hline R-squared & 0,9975 & Rataan variabel dependen & 32,48476 \\
\hline Penyesuaian R-squared & 0,9963 & S.D. variabel dependen & 68,33937 \\
\hline S.E. dari regresi & 1,0100 & Sum squared residual & 45,90313 \\
\hline F-Statistic & 887,0116 & Statistik Durbin-Watson & 1,80389 \\
\hline Probabilitas (F-Statistic) & 0,0000 & & \\
\hline Statistik tanpa pembobot & 0,8786320 & Rataan variabel dependen & 0,000567 \\
\hline R-squared & 0,0000026 & Statistik Durbin-Watson & 1,535568 \\
\hline Sum squared residual & &
\end{tabular}


Multikolinearitas disebabkan oleh nilai R-squared yang tinggi, tetapi variabel-variabel independennya hanya sedikit yang tidak signifikan (Bell et al. 2014). Dalam Ratnasari et al. (2014) dan Akbar et al. (2011), Uji multikolinearitas dapat dilakukan dengan membandingkan nilai probabilitas dan matrik korelasi antar variabel. Pada model daya saing furniture rotan Indonesia nilai R-squared adalah 0,9975 dan 12 dari 15 variabel bebas yang siginifikan, menunjukkan bahwa model terbebas dari masalah multikolinearitas. Nilai R-squared ini menunjukkan bahwa 99,75\% keragaman variabel dependen dapat dijelaskan oleh variabelvariabel independennya yang terdapat dalam model, sedangkan sisanya dijelaskan oleh variabel independen diluar model.

Hasil estimasi model daya saing furniture rotan Indonesia menunjukkan bahwa Sum Square Residual pada Weighted Statistics sebesar 45.903 jauh lebih besar dari Sum Square Residual pada Unweighted Statistics sebesar 2,6 x 10-6. Artinya, dapat disimpulkan bahwa pada model daya saing furniture rotan Indonesia terbebas dari masalah heteroskedastisitas. Pembobotan dengan cross-section SUR pada FEM dalam Pusakasari (2014) dapat digunakan untuk mengatasi heterokedastisitas dan korelasi antar unit cross-section yang terdapat pada data pengamatan tentang NRCA di enam negara tersebut.

Uji autokorelasi dapat dilakukan dengan melihat nilai Durbin Watson (DW). Dengan jumlah observasi 66, jumlah variabel independen sebanyak 15 dan $\alpha$ sebesar 5\% maka diperoleh nilai Durbin-Watson tabel dengan DL sebesar 1,098, DU sebesar 2,176 dan DurbinWatson stat dengan Weighted Statistics sebesar 1,804. Maka nilai DW berada diantara $\mathrm{DL}<\mathrm{DW}<\mathrm{DU}$. Artinya, tidak dapat disimpulkan apakah masalah autokorelasi terdapat pada model, namun karena sudah diboboti masalah autokorelasi ini dapat diabaikan.

1. Harga ekspor furniture rotan Indonesia ke ASEAN dan Tiongkok (HEX)

Pada dasarnya, harga ekspor furniture rotan menggambarkan mutu dan kualitas furniture rotan itu sendiri. Semakin tinggi harga ekspor furniture rotan Indonesia menandakan bahwa mutu dan kualitas furniture rotan Indonesia semakin baik sehingga daya saing Indonesia yang direpresentasikan dengan indeks
NRCA juga semakin tinggi di pasar Internasional. Probabilitas variabel harga ekspor furniture rotan Indonesia ke negara tujuan menunjukan pengaruh yang signifikan dan positif pada taraf nyata $5 \%$. Hal ini menunjukan bahwa variabel harga ekspor produk olahan rotan Indonesia merupakan salah satu faktor yang memengaruhi daya saing furniture rotan Indonesia. Nilai koefisien harga ekspor adalah 0,00012. Artinya, jika harga ekspor furniture rotan Indonesia naik sebesar $1 \%$ maka daya saing furniture rotan Indonesia akan meningkat sebesar $0,00012 \%$ (ceteris paribus).

\section{Volume ekspor furniture rotan Indonesia ke ASEAN dan Tiongkok (VEX)}

Hasil estimasi data panel, dapat diketahui bahwa volume ekspor furniture rotan berpengaruh positif terhadap daya saing produk olahan rotan Indonesia. Nilai koefisien sebesar 1,53 x 10-10 menandakan bahwa setiap kenaikan $1 \%$ volume ekspor furniture rotan akan meningkatkan daya saing furniture rotan Indonesia sebesar $1,53 \times 10^{-10 \%}$ (ceteris paribus). Volume ekspor furniture rotan menggambarkan permintaan neraga ASEAN dan Tiongkok terhadap furniture rotan Indonesia. Semakin tinggi volume ekspor furniture rotan maka hasil produk furniture rotan Indonesia akan semakin diminati di pasar ASEAN dan Tiongkok. Hal ini akan berdampak pada peningkatan daya saing furniture rotan Indonesia.

\section{Harga furniture rotan dunia (HFW)}

Hasil estimasi menunjukkan harga furniture rotan dunia berpengaruh negatif dan signifikan terhadap daya saing furniture rotan Indonesia dengan nilai probabilitas variabel harga furniture rotan dunia lebih kecil dari taraf nyata $5 \%$. Peningkatan harga furniture rotan dunia justru membuat daya saing furniture rotan Indonesia di kawasan ASEAN dan Tiongkok semakin menurun. Setiap kenaikan harga ekspor furniture rotan dunia sebesar 1\%, justru menurunkan daya saing furniture rotan Indonesia sebesar 0,000195\% (ceteris paribus). Harga furniture rotan dunia dapat dikatakan menjadi pesaing dari harga furniture rotan dari Indonesia. Mengingat semakin tinggi harga furniture rotan dunia menandakan bahwa mutu dan kualitas furniture rotan selain dari Indonesia semakin baik sehingga daya saing Indonesia menjadi menurun. 


\section{Harga rotan mentah dunia}

Peran industri furniture rotan Indonesia tidak mampu menyerap seluruh bahan baku rotan yang ada. Akibatnya, sisa rotan mentah diekspor ke pasar dunia secara ilegal dan dapat menekan harga jual rotan mentah sehingga menyebabkan harga rotan mentah jatuh, petani dirugikan dan perekonomian industri rotan sulit untuk berkembang. Hasil estimasi data panel, harga rotan mentah dunia berpengaruh positif terhadap daya saing produk olahan rotan Indonesia. Variabel harga rotan mentah di dunia yang ditunjukkan pada model regresi mempunyai pengaruh positif dan signifikan terhadap daya saing furniture rotan Indonesia dengan nilai probabilitas yang lebih kecil dari taraf nyata $5 \%$. Artinya, peningkatan jumlah perusahaan pengolahan rotan di Indonesia sebesar 1\% dapat meningkatkan produksi rotan di Indonesia dan imbasnya pada peningkatan daya saingnya sebesar $1,56 \times 10^{-40} \%$ (ceteris paribus).

5. Jumlah perusahaan pengolahan rotan di Indonesia (IND)

Pada dasarnya potensi rotan Indonesia masih belum terberdayakan secara penuh. Sebagai gambaran, potensi rotan di Indonesia mencapai 17.217.442 ton (Kemenperin, 2012). Tetapi, hingga saat ini baru sekitar 170 ribu ton hasil produksi rotan per tahun yang mampu diproduksi oleh industri rotan dalam negeri. Oleh sebab itu, ada potensi besar dari rotan yang belum terberdayakan. Jika pemerintah mampu mengubah potensi rotan menjadi suatu produk jadi olahan rotan dengan cara menambah jumlah perusahaan pengolahan rotan, maka nilai perdagangan Internasional dari industri furniture rotan dalam negeri akan dapat meningkat. Variabel jumlah perusahaan pengolahan rotan Indonesia yang ditunjukkan pada model regresi mempunyai pengaruh positif dan signifikan terhadap daya saing furniture rotan Indonesia dengan nilai probabilitas yang lebih kecil dari tarafnyata $5 \%$. Artinya, peningkatan jumlah perusahaan pengolahan rotan di Indonesia sebesar $1 \%$ dapat meningkatkan produksi rotan di Indonesia dan imbasnya pada peningkatan daya saingnya sebesar $0,0000225 \%$ (ceteris paribus).

\section{Produksi riil rotan di Indonesia (PRD)}

Hasil estimasi pada model menunjukkan bahwa nilai probabilitas variabel produksi riil rotan di Indonesia bernilai 0,0000 . Artinya, lebih kecil dari taraf nyata
5\%. Hal ini menunjukan bahwa variabel produksi riil rotan di Indonesia berpengaruh signifikan terhadap daya saing furniture rotan Indonesia. Variabel produksi riil rotan di Indonesia memiliki pengaruh yang negatif terhadap daya saing furniture rotan Indonesia dimana dari model regresi didapatkan hasil bahwa dengan menambah produksi rotan di Indonesia ternyata tidak menambah daya saing furniture rotan Indonesia di pasar Internasional. Hal ini disebabkan, jumlah produksi ditambah, tetapi konsumsi rotan yang digunakan untuk industri furniture rotan tidak ditingkatkan. Sebaliknya, melimpahnya bahan baku rotan mentah membuat harganya semakin menurun. Petani enggan memanen rotan di dalam hutan dengan alasan tidak lagi menguntungkan. Meskipun, mempunyai pengaruh yang negatif dan signifikan, pengaruh produksi riil rotan Indonesia mempunyai pengaruh yang kecil terhadap daya saing furniture rotan Indonesia. Nilai koefisien dari regresi untuk variabel produksi riil rotan di Indonesia yang sangat kecil, yaitu hanya sebesar $1,26 \times 10^{-8}$ yang menjadi parameternya. Artinya, dengan bertambahnya produksi rotan mentah di Indonesia sebesar 1\% justru menurunkan daya saing furniture rotan Indonesia hanya sebesar $1,26 \times 10^{-80} \%$ (ceteris paribus).

\section{Nilai produksi furniture rotan Indonesia (VAL)}

Hasil estimasi pada model regresi dapat diketahui bahwa nilai produksi furniture rotan Indonesia berpengaruh positif dan signifikan terhadap daya saing furniture rotan Indonesia meskipun memiliki nilai koefisien yang sangat kecil, yaitu sebesar 5,91 x 10-12. Hal ini menandakan bahwa setiap kenaikan $1 \%$ nilai produksi furniture rotan Indonesia dapat meningkatkan daya saing furniture rotan Indonesia sebesar 5,91 x $10^{-12 \%}$ (ceteris paribus). Besarnya nilai produksi dari industri furniture rotan Indonesia tersebut dipengaruhi oleh adanya sumber daya tenaga kerja yang cukup dan pasokan bahan baku rotan yang cukup pula untuk pengembangan industri furniture rotan yang ada di Indonesia. Semakin tinggi nilai produksi rotan di Indonesia mengindikasikan bahwa semakin banyaknya produksi furniture rotan. Hal ini berdampak pada peningkatan daya saing furniture rotan Indonesia.

\section{Investasi pengolahan rotan Indonesia (INV)}

Nilai probabilitas variabel investasi pengolahan rotan Indonesia, yaitu sebesar 0,0000 dimana lebih kecil dari taraf nyata $5 \%$. Hal ini menunjukan bahwa variabel investasi pengolahan rotan Indonesia berpengaruh 
positif dan signifikan terhadap daya saing furniture rotan Indonesia. Nilai koefisien investasi pengolahan rotan di Indonesia memiliki nilai 2,10 x 10 $0^{-11}$. Artinya, akibat adanya peningkatan investasi pengolahan rotan di Indonesia sebesar 1\% dapat meningkatkan daya saing furniture rotan Indonesia meskipun hanya sebesar $2,10 \times 10^{-11 \%}$, ceteris paribus. Dengan ditingkatkannya jumlah investasi terhadap pengolahan rotan di Indonesia dapat menumbuhkan perusahaan pengolahan rotan di Indonesia. Hal ini berpengaruh langsung terhadap peningkatan daya saing furniture rotan Indonesia di kawasan ASEAN dan Tiongkok.

9. Tenaga kerja langsung industri rotan Indonesia (LBR)

Variabel tenaga kerja industri rotan Indonesia memiliki pengaruh negatif dan signifikan terhadap daya saing furniture rotan Indonesia. Variabel ini memengaruhi besarnya daya saing furniture rotan Indonesia ke ASEAN dan Tiongkok dengan nilai koefisien sebesar $-5,46 \times 10^{-9}$. Ternyata, menambah tenaga kerja langsung pada industri furniture rotan Indonesia justru menurunkan daya saing furniture rotan itu sendiri. Dari nilai koefisien tersebut menunjukkan bahwa apabila terjadi peningkatan jumlah tenaga kerja langsung pada industri rotan di Indonesia sebesar 1\% justru menyebabkan penurunan daya saing fueniture rotan Indonesia ke ASEAN dan Tiongkok sebesar 5,46 x 10-9\% dari jumlah sebelumnya, ceteris paribus. Sebagaimana kita ketahui, teknologi yang digunakan dalam proses produksi furniture rotan di Indonesia masih sederhana dan masih tergantung terhadap cuaca sehingga memengaruhi kualitas dan kuantitas produk furniture rotan Indonesia. Menambah tenaga kerja langsung pada industri rotan sementara teknologi proses produksi furniture rotan yang digunakan masih sederhana justru membuat biaya pada tenaga kerja menjadi semakin besar daripada keuntungan peningakatan jumlah produksi furniture rotan Indonesia.

\section{Perbandingan lending rate dengan Negara $\mathrm{j}$ (LDR)}

Akhir-akhir ini, pengusaha furniture rotan masih mengeluhkan tingginya tingkat suku bunga di Indonesia. Suku bunga perbankan erat kaitannya dengan kelayakan usaha yang dilakukan, semakin tinggi tingkat suku bunga perbankan (suku bunga pinjaman) maka para pemilik modal akan enggan menanamkan modalnya pada usaha industri furniture rotan. Hasil pengujian pada model regresi menunjukan bahwa nilai probabilitas variabel perbandingan tingkat suku bunga Indonesia dengan Negara pesaing sebesar 0,0016 dimana lebih kecil dari taraf nyata 5\%. Hal ini menunjukan bahwa variabel perbandingan tingkat suku bunga Indonesia dengan Negara pesaing berpengaruh signifikan terhadap daya saing furniture rotan Indonesia. Nilai koefisien perbandingan tingkat suku bunga Indonesia dengan Negara pesaing memiliki nilai $-0,000182$. Artinya, setiap peningkatan perbandingan tingkat suku bunga Indonesia dengan Negara pesaing sebesar $1 \%$ dapat dapat menurunkan daya saing furniture rotan Indonesia sebesar $0,000182 \%$, ceteris paribus.

\section{Dummy diberlakukannya ASEAN-China Free Trade} Agreement (ACF)

Perjanjian ACFTA merupakan penandatangan kerja sama antara negara-negara ASEAN dan Tiongkok yang dimulai pada Tahun 2010 untuk mengurangi hambatan perdagangan, salah satunya dengan penurunan tarif. Biaya masuk suatu produk barang akan menjadi lebih murah ketika biaya tarif diturunkan sehingga menyebabkan harga produk menjadi lebih murah dan semakin kompetitif. Semakin murah harga suatu produk akan memberikan insentif bagi konsumen untuk terus meningkatkan permintaan mereka sehingga ekspor furniture rotan Indonesia juga semakin meningkat. Hasil pengujian pada model menunjukan bahwa nilai probabilitas variabel dummy ACFTA sebesar 0,0000 . Hal ini menjelaskan bahwa pemberlakuan ACFTA berpengaruh signifikan terhadap perubahan daya saing furniture rotan Indonesia. Nilai koefisien dummy ACFTA sebesar -0,000511. Artinya, akibat diberlakukannya ACFTA, daya saing furniture rotan Indonesiajustru menjadilebih rendah 0,000511 kali ratarata daya saing furniture rotan Indonesia dibandingkan sebelum diberlakukan ACFTA, ceteris paribus. Hal itu menandakan bahwa dengan adanya ACFTA, industri furniture Indonesia belum bisa bersaing.

12. Dummy kebijakan domestik pemerintah Indonesia (PLC)

Nilai probabilitas dummy kebijakan pemerintah, yaitu 0,0000 lebih kecil dari taraf nyata 5\%. Hal ini menunjukan bahwa dummy kebijakan pemerintah atas ditutupnya aliran ekspor bahan baku mentah rotan maupun setengah jadi berpengaruh signifikan terhadap daya saing furniture rotan Indonesia. Nilai koefisien dummy kebijakan pemerintah sebesar 0,0013. 
Artinya, akibat kebijakan pemerintah atas pelarangan mengekspor rotan mentah maupun setengah jadi, daya saing furniture rotan Indonesia meningkat sebesar 0,0013 kali dari rata-rata daya saing furniture rotan Indonesia dibandingkan sebelum diberlakukan kebijakan pemerintah tersebut, ceteris paribus. Dilarangnya ekspor bahan baku rotan mentah ke luar negeri akan membuat pasokan bahan baku rotan digunakan untuk memenuhi kebutuhan bahan baku industri pengolahan rotan Indonesia sehingga dapat meningkatkan daya saing furniture rotan Indonesia.

\section{Rekomendasi Strategi Peningkatan Daya Saing Furniture Rotan Indonesia di Kawasan ASEAN dan Tiongkok}

a. Pendirian pusat pengembangan atau pusat pelatihan dan pengembangan desain yang inovatif maupun standart mutu furniture rotan Indonesia

Melihat dari faktor-faktor yang berpengaruh terhadap daya saing furniture rotan Indonesia berdasarkan FEM terhadap variabel dependen NRCA, yaitu harga ekspor, volume ekspor, harga furniture rotan dunia dan harga rotan mentah dunia. Oleh karena itu, pengembangan desain yang inovatif dan standart mutu yang tinggi perlu dilakukan agar dapat meningkatkan daya saingnya. Menurut Maharani \& Handojo (2012), minimnya desain yang dibuat secara independen oleh industri ini membuat nilai jual produk furniture rotan Indonesia masih tergantung dan dikontrol oleh buyer.

Selain desain, aspek sumber daya manusia juga sangat berpengaruh terhadap desain furniture rotan yang baru dan inovatif. Penelitian Sriwarno (2004) menunjukkan bahwa banyak sekali tenaga kerja perusahaan furniture rotan yang kurang terdidik. Aspek rendahnya kualitas pendidikan akan berpengaruh terhadap perilaku dan apresiasi masyarakat terhadap desain furniture rotan. Pengembangkan pusat pelatihan dan desain dengan menggandeng perguruan tinggi diharapkan dapat memecahkan masalah sumberdaya manusia saat ini.

b. Menjamin ketersediaan bahan baku rotan dan peningkatan teknologi industri pengolahan rotan

Potensi rotan dari hutan alam sangat tergantung pada kondisi hutannya. Kerusakan hutan dan pengalihan fungsi kawasan dapat menjadi ancaman bagi tanaman rotan. Akibat terganggunya habitat rotan maka potensi rotan dapat terus menurun, sedangkan di sisi lain pembudidayaan rotan masih dilakukan secara terbatas. Faktor jumlah industri pengolahan rotan di Indonesia, jumlah investasi, produksi riil rotan dan nilai produksi rotan tersebut dalam pembahasan regresi FEM diketahui memengaruhi daya saing furniture rotan Indonesia. Dengan kondisi saat ini bahwa pengambilan bahan baku rotan masih bergantung sepenuhnya dari hutan, pemerintah diharapkan lebih giat lagi dalam upaya pengelolaan hutan di Indonesia serta mendukung program pembudidayaan tanaman rotan.

Dalam hal proses pengolahan rotan, teknologi yang digunakan saat ini masih tradisional sehingga hal inilah yang menjadi salah satu kendala furniture rotan Indonesia belum bisa bersaing di level Internasional. Faktor tenaga kerja langsung dalam regresi FEM mempunyai pengaruh yang negatif. Artinya, dalam peningkatan daya saing furniture rotan di Indonesia saat ini, industri-industri furniture rotan Indonesia harus dapat mengurangi jumlah tenaga kerja langsung dan menggantinya dengan teknologi pengolahan rotan yang lebih modern dan tidak bergantung kepada cuaca.

c. Perbaikan infrastruktur maupun rantai distribusi, perbaikan sistem informasi pasar rotan Serta penguatan brand image furniture rotan Indonesia

Penghentian ekspor bahan baku rotan ternyata belum membuat industri furniture rotan di Indonesia mendapat pasokan bahan baku yang memadai. Sejumlah pengrajin di daerah asal bahan baku rotan seperti Cirebon, Semarang, Surabaya, Jakarta dan daerah industri pengolah bahan baku rotan tetap kekurangan bahan baku. Kesulitan mendapatkan bahan baku ini disebabkan oleh kelangkaan yang terjadi karena sistem perdagangan dan distribusi antar pulau yang kurang baik, sehingga rotan dari Sumatera, Kalimantan dan Sulawesi sulit masuk ke Pulau Jawa (Dewi, 2015). Pemerintah daerah asal bahan baku rotan diharapkan dapat membangun industri hulu yang dapat memenuhi kebutuhan pasokan bahan baku industri hilir. Bagi pengusaha industri furniture rotan, jaringan pendistribusian bahan baku rotan ini saja belum cukup untuk meningkatkan daya saing furniture rotan di pasar Internasional. Perlu perbaikan sistem informasi pasar serta pembentukan brand image furniture rotan Indonesia. Pembentukan brand image rotan Indonesia adalah suatu hal yang tidak mudah. Perlu modal besar untuk keperluan promosi dan layanan penjualannya. Dengan kondisi tingginya pinjaman bunga Bank di Indonesia saat ini dapat mengakibatkan para pemilik 
modal enggan menanamkan modalnya pada industri furniture rotan di Indonesia. Pemerintah diharapkan dapat menekan tingginya suku bunga Bank di Indonesia yang rata-rata lebih tinggi jika dibandingkan dengan 5 negara ASEAN dan Tiongkok.

\section{KESIMPULAN DAN SARAN}

\section{Kesimpulan}

Daya saing furniture rotan Indonesia di kawasan ASEAN dan Tiongkok dalam kurun waktu 2001 hingga 2014 berfluktuasi dan sebenarnya masih mempunyai daya saing meskipun kecil, hal ini dapat dilihat dari semua nilai indeks NRCA nilainya positif.

Pada FEM daya saing furniture rotan Indonesia, variabel independen yang berpengaruh signifikan terhadap NRCA adalah harga ekspor, volume ekspor, harga furniture rotan dunia, harga rotan mentah dunia, jumlah perusahaan industri rotan di Indonesia, produksi rotan riil di Indonesia, nilai produksi rotan di Indonesia, investasi industri rotan di Indonesia, tenaga kerja langsung industri rotan, besarnya suku bunga pinjaman Bank, pemberlakuan ACFTA dan kebijakan pelarangan ekspor rotan mentah maupun setengah jadi.

Dalam meningkatkan daya saing furniture rotan yang direpresentasikan oleh indeks NRCA, pemerintah harus mendirikan pusat pengembangan atau pelatihan dan pengembangan desain yang inovatif maupun standart mutu furniture rotan Indonesia. Hal ini juga didukung dengan adanya jaminan ketersediaan bahan baku rotan dan peningkatan teknologi industri pengolahan rotan. Hal ketiga yang perlu dilakukan dalam peningkatan daya saing furniture rotan adalah perbaikan infrastruktur maupun rantai distribusi, perbaikan sistem informasi pasar rotan serta penguatan brand image furniture rotan Indonesia.

\section{Saran}

Pada penelitian ini, variabel ACFTA berpengaruh signifikan namun mempunyai nilai yang negatif. Perlu dilakukan penelitian lebih lanjut dan mendalam untuk dapat mengetahui pengaruh yang sebenarnya.

\section{DAFTAR PUSTAKA}

Akbar A, Imdadullah M, Ullah MA, Aslam M. 2011. Determinants of economic growth in Asian countries: a panel data perspective. Pakistan Journal of Social Sciences 31(1):145-157.

Anwar MF, Darsono, Agustono. 2014. Analisis daya saing industri furniture rotan Kabupaten Sukoharjo. E-jurnal Agrista 4(2):1-10.

Bell A, Jones K. 2014. Explaining fixed effects: random effects modeling of time-series cross-sectional and panel data. Political Science Research and Methods 3(1):133-153.

Daryanto A. 2004. Keunggulan daya saing dan teknik Identifikasi komoditas unggulan: dalam mengembangkan potensi ekonomi regional. Agrimedia 9(2):51-62.

Dewi NK, Miharja M, Yudoko G. 2015. Analisis kebijakan distribusi bahan baku rotan dengan pendekatan dinamik sistem studi kasus rotan Indonesia. Jurnal Perencanaan Wilayah dan Kota 26(3): 177-191.

Dobbs ME. 2012. Porter's five forces in practice: templates for firm and case analysis. CF Eastern Illinois University Journal 10(1):22-33.

Hermawan M. 2012. Export performance development of Indonesia's textile and apparel product: a comparative advantage study. Jurnal Badan Pendidikan dan Pelatihan Keuangan 5:15-30.

Karagiannopoulos GD, Georgopoulos N, Nikolopoulos K. 2005. Fathoming Porter's five forces model in the internet era. The Journal of Policy, Regulation and Strategy for Telecommunications, Information and Media 7(6):66-76.

Kirchner M. 2012. Porter's five forces in the finishing industry. Products Finishing 76(12):52-53.

Maharani NY, Handojo O. 2012. Eksplorasi struktur dan kombinasi material produk furnitur rotan. Jurnal Tingkat Sarjana Senirupa dan Desain ITB 1: 1-6.

Nayantakaningtyas JS, Daryanto HK. 2012. Daya saing dan strategi pengembangan minyak sawit di Indonesia. Jurnal Manajemen dan Agribisnis 9(3):194-201

Porter ME. 1998. The Competitive Advantage of Nations. New York: Free Press.

[UNComtrade] United Nation Commodity Trade. 2001-2014. 2015. United Nation Commodity Trade Statistic Database. www.un.comtrade.org [26 Januari 2015]. 
Pusakasari AS. 2014. Regresi panel dengan metode weighted cross-section SUR pada data pengamatan gross domestic product dengan heterokedastisitas dan korelasi antar individu (cross-section correlation). Jurnal Mahasiswa Statistik 2(6):477-480.

Ratnasari NPAM, Kencana IPEN, Gandhiadi GK. 2014. Aplikasi regresi data panel dengan pendekatan Fixed Effect Model (studi kasus: PT PLN Gianyar). E-Jurnal Matematika 3(1):1-7.

Sanidas E, Shin Y. 2010. Comparison of Revealed Comparative Advantage Indices with Application to Trade Tendencies of East Asian Countries. 9th Korea and the World Economy Conference. Incheon.
SilalahiD, Sitepu R, Tarigan G. 2014. Analisis ketahanan pangan provinsi Sumatera Utara dengan metode regresi data panel. Saintia Matematika 2(3): 237-251.

Sriwarno. 2004. Konteks usaha pengembangan desain mebel rotan di lingkungan industri rotan Cirebon dan penerapan sistem HKI (Hak Kekayaan Intelektual). Jurnal Desain 2d3D 1(2): 99-124.

Sumardjani L. 2009. Konsep lima kekuatan Porter untuk membedah kondisi industri rotan Indonesia. Jurnal Manajemen Hutan Tropika 15(1):41-44.

Yu R, Cai J, Leung PS. 2009. The normalized revealed comparative advantage index. The Annals of Regional Science 43(1):267-282. 